\title{
The Integration between Strategic Cost Management Techniques to Improve the Performance of Iraqi Manufacturing Companies
}

\author{
Khalis Al-Naser (Corresponding author) \\ College of Administration \& Economic \\ University of Mosul, Iraq \\ Tel: 60-1-8286-5404Ｅ-mail: alnaser7171@yahoo.com \\ Rapiah Mohamed \\ Tunku PuteriIntan Safinaz School of Accountancy \\ Universiti Utara Malaysia, 06010 Sintok, Kedah, Malaysia \\ Tel: 60-1-2425 7275 E-mail: rapiah@uum.edu.my
}

Received: Jan. 22, 2017 Accepted: March 14, $2017 \quad$ Published: June 1, 2017

doi:10.5296/ajfa.v9i1.11003 URL: https://doi.org/10.5296/ajfa.v9i1.11003

\begin{abstract}
The performance of manufacturing industry in Iraq has been declining over the last few decades. Worst still, many companies in the manufacturing sector in Iraq are yet to adopt Balanced Scorecard (BSC) to improve their performance despite its potency ensure to achieve competitive advantage and better performance. This study examines the integration between Total Quality Management (TQM) and BSC four perspectives in Iraqi manufacturing industry. Data were collected by means of structured questionnaire survey using simple random sampling and a Partial Least Squares (PLS) algorithm and bootstrap techniques were used to test the hypothesis of the paper. The result revealed that TQM had a significant positive effect on BSC through the measurement of customer perspective, financial perspective, innovation and learning perspective, and internal business process perspective. The finding implies that Iraqi manufacturing industries can attain the performance of their companies in the different perspective of BSC by proper implementation of TQM technique.
\end{abstract}

Keywords: Strategic Cost Management Techniques, BSC, TQM, Iraq 


\section{Introduction}

While there were no noteworthy changes in managerial accounting practice from the 1930s to 1980s (Johnson and Kaplan, 1987), the most recent two decades have seen a restored enthusiasm to push the boondocks of information here. "The old accounting framework, which reveals to us the cost of material and labor, is not appropriate. Indeed, even in assembling, maybe three-fourth of the value included gets from learning". The accentuation has been to incorporate non-financial measures in the assessment and performance measurement models and to discover control systems for the new economy ventures and how to make them more receptive to the worldwide and temporary open doors. Striking cases of these developments around there incorporate, Balanced Scorecard, Activity-Based Costing, Activity-Based Management, Total Quality Management, Agile Manufacturing, Just in Time Inventory and Theory of Constraints (Gunasekaran, 2005).

Therefore, this paper was set to examine the integration between strategic cost management techniques (TQM and BSC) in Iraq's manufacturing industry with the sole aim of improving firm performance which has become one of the essential concerns for the managers of all organizations (Acer \& Acer, 2014; Pimentel \& Major, 2014). Several organizations worldwide continuously work to improve their performance through various techniques. The ability of the top management to set appropriate firm activities and strategies will determine the strength of the organization in maintaining its performance in the long term (Lynch \& Cross, 1992; Neely, Mills, Platts, Gregory, \& Richards, 1994).

In the context of manufacturing industry in Iraq, despite its contribution to the country's GDP (Central Bank of Iraq Annual Report (CBIAR), 2013), the performance of manufacturing industry has been declining over the last few decades (Harash, Al-Tamimi \& Al-Timimi, 2014; Saleh, 2015). The sector has been under pressure and challenges since 1990 (Hafedh, Akoum, Zbib \& Ahmed, 2007). Previous studies and annual reports have shown that the performance of manufacturing sector is weak as compared with other sectors, such as banking and other service sectors (Bureihi, 2011; CBIAR, 2013). Previous management accounting research criticized the idea of relying only on traditional performance measures that are financial in nature and stresses the importance of using a combination of performance measures. The reason behind this is that the combination of financial and non-financial measures is considered as more effective in evaluating performance (Atkinson et al, 1997; Chenhall \& Langfield-Smith, 2007; Hoque, Mia, \& Alam, 2001; Kaplan \& Norton, 1992, 1993; Pimentel \& Major, 2014). The trend of using non-financial measures is increasing in order to integrate it with accounting performance measures that are only financial. Thus, this is amongst the key factors for the development of PMS (Elijido-Ten, 2010). One of the famous PMS models is the BSC (Pimentel \& Major, 2014). This model was originated by Kaplan and Norton in 1992. BSC is considered as the most important technique in the area of strategic cost management (Gunasekaran, 2005; Malleret, 2015) that provides information for strategic decision-making. Besides that, it includes three non-financial aspects like customers, learning and growth, and internal operations of businesses (Kaplan \& Norton, 2001). Many authors mentioned the importance of the BSC as an important source to improve firm performance (Kaplan\& Norton, 1992; Sandström \& Toivanen, 2002). 
Therefore, the important of BSC to the modern business, matching with yet another important technique of strategic cost management: TQM may address the peculiar problem of manufacturing industry of Iraq as many companies in the manufacturing sector in Iraq are still to come to terms with decision about adoption of BSC to improve their performance (Al-Naser, 2010; Suror, 2014) despite its potency to improve firm performance that ensures sustainable competitive edge (Mohamed, Abdul Rahman \& Abdul Aziz, 2010). Again, the literature is yet to have sufficiently established a relationship between TQM and BSC performance measures. A number of the determined the effect of TQM and organizational performance (Mehralian et al., 2017; Peljhan, D., \& Marc, 2016; Shafiq Lasrado \& Hafeez, 2017; Sweis, Ahmad, Dweik, Alawneh \& Hammad, 2016). Others used BSC to mediate between TQM and organizational performance Sholihin \& Laksmi, 2009). Also, there is no specific study has examined the effect and relationship of TQM and BSC performance measures as set in this paper.

In view of the above, the rest part of this study is structured as follows: The next section discusses literature review, and research framework, followed by the methodology section, then result and conclusion.

\section{Literature Review and Hypotheses Development}

\subsection{Total Quality Management (TQM)}

TQM, part of strategic cost management techniques (Hertati \& Sumantri, 2016; Hertati, 2015; Ayedh \& Houssem Eddine, 2015; Ibrahim, Sukeri \& Rashid, 2014). Long profitability of the business and firm performance can be enhanced by the adoption of TQM in the organization (Wilkinson, Marchington, Goodman \& Ackers, 1992). This is in conformity with the attention gained by TQM in its effect on firm performance these last few years. It is argued that implementing TQM helps in achieving improvement in the quality of the product, and it assists in cost reduction as well, which ultimately results in customer satisfaction and enhanced financial gains (Walton, 1986).

Similarly, Prajogo and Brown (2004) have also highlighted that implementation of TQM practices has enhanced quality performance of Australian organizations. The researchers compared organizations that have implemented TQM with those that have not implemented TQM formally. Initially, it was observed that TQM practices improved performance a lot but later on it was observed that TQM practices do not have a significant impact on all the quality assurances since it only improves management of procedures and strategic planning. The final part of the study totally negates the relationship by arguing that implementation of TQM does not improve the complete relationship between implementation of TQM practices and Performance of organizations. Regardless of the variations in the results in different time periods, the researchers argued that implementation of TQM has a certain benefit. In short, the study revealed that implementation of TQM always has significant predictive capacity over quality firm performance. Thus, it would be right to say that it is critical for the organizations to implement TQM as a set of practices as compared to only implementing TQM as the formal program for enhancing performance. 
Again, despite the contradictory arguments of some researchers, there are certain researchers that argue that TQM helps in improvement of firm performance. Errikson and Hansson (2003) argued that TQM helps to improve the financial performance of Swedish organizations. The researchers have compared the Swedish recipients of the quality award with branch indices for the identification of competitors. Initially, it was observed that implementation of TQM has no impact on financial performance but later on it was seen that implementation of TQM has a positive impact on the firm performance. The researchers observed the change in sales, change in a number of employees, and profit margins on sales. They found that companies that have implemented TQM successfully have experienced significant improvement in the firm performance as compared to their competitors.

\subsection{Balanced Scorecard (BSC)}

Preceding BSC, Shank (1989) proposes the mixing of three subjects: value chain analysis, strategic positioning analysis and cost driver analysis from the strategic administration writing to end up distinctly a structure called "SCM" Since methodology and vision are of importance to every one of the partners in the association, then Kaplan and Norton (1992) built up another performance measurement framework called BSC which mulls over the need of client, interior business and advancement and learning points of view close by a financial viewpoint, and characterizing future introduction. In the contemporary, the BSC is regarded among the top most developments in the field of Management accounting. In fact, several researchers and academicians have empirically recognized the need and importance of BSC towards enhancing the performance of an organization (Norreklit, Norreklit, Mitchell, \& Bjomenak, 2012; Hoque, 2014). The importance of BSC implications can be judged by the arguments given in favour of BSC by Towers Perrin Consulting organizational (Hoque \& James, 2000; Hoque et al. 2001; Widener, 2006).

Indeed, generally, it is accepted that companies that implement formal PMS that are balanced in terms of financial and non-financial indicators will stand ahead of their competitors (Kartalis, Velentzas \& Broni, 2013). BSC by its name shows the balanced considerations that are given to long-term as well as short-term financial and non-financial objectives of the organization. BSC cover four different perspectives including; the perspective of innovation and learning, the perspective of business, the perspective of the customer, and last but not the least the financial perspective (Kaplan \& Norton, 1992). These perspectives are used as the holistic performance measures that are helping the organization to stay on course. Given the importance of BSC, there is a dire need of intense research in the field. Despite its dire need and importance, limited empirical support is available in the field, thereby indicating an on-going research in this perspective.

\subsection{Total Quality Management and Balanced Scorecard}

The purpose of linking BSC and TQM is to harmonize vision, strategy, operation, and employees. Organizations implementing TQM for the achievement of strategic goals should incorporate measures of BSC to determine appropriate multidimensional indicators that are financial and non-financial. By doing so, organization motivates the employees through reward systems that are tailored according to the necessary outcomes. Organizations also 
encourage and reward those who provide feedback that assists the organizations to improve (Hoque, 2003). Feedback is the basis for the success of any organization. Feedback empowers employees to achieve continuous improvement through which success is achieved which is the core element of TQM (Sunhilde, 2009).

This study linked BSC and TQM for identification of opportunities. In the current literature, this linkage has not yet been explored especially in the Arab region. As mentioned above that BSC is more inclined towards financial concerns and TQM is more inclined towards systems. However, TQM practices do not ignore the importance of financial solvency. Considering the importance of integration between TQM and BSC more and more organizations are adopting TQM and BSC integrated control systems (Lin \& Johnson, 2004). Vora (2002) supported the argument and suggested that TQM strategies are in line with BSC. Based on the abovementioned discussion the relationship has been hypothesized as follows:

H1: There is a relationship between TQM and financial perspective of BSC

H2: There is a relationship between TQM and customer perspective of BSC

H3: There is a relationship between TQM and internal business process perspective of BSC

H4: There is a relationship between TQM and innovation and learning perspective of BSC

\subsection{Research Framework}

Based on the literature reviewed and the subsequent development of hypothesis, figure 1 presents the pictorial positions of the research framework.

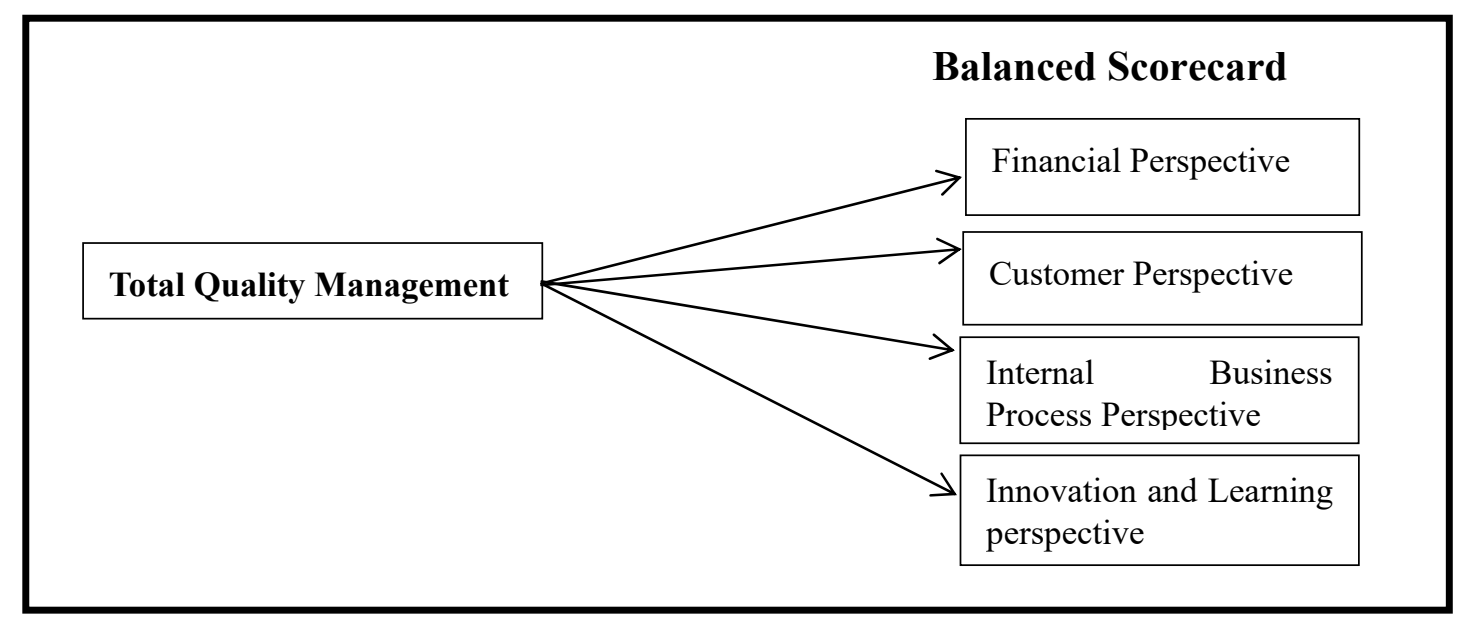

Figure 1. Research Framework

As shown in figure 1, the research framework has total quality management as the only independent variable and corresponding dependent variable is balance scorecard with four dimensions. Hypotheses were developed between the TQM and the four dimensions of BSC (financial perspective, customer perspective, internal business process perspective, and innovation and learning perspective). 


\section{Methodology}

This research adopts a cross-sectional field survey technique. Using structured questionnaire, data was collected at one time through probability sampling for the best liners and un-bias estimate for generalizations.

\subsection{Sampling and data}

Simple random sampling technique was used in this paper and data was collected using a questionnaire that was distributed to 604 manufacturing companies in Iraq i.e twice the actual sample size (302, based on Krejcie and Morgan (1970) guideline) of the study to avoid low response rate as guided by Hair, Wolfinbarger \& Ortinail (2008). The main sampling targets were top managers of the manufacturing firm. The survey provided us with 303 completed questionnaires constituting a response rate of $50.2 \%$, which provided an adequate sample for analyses.

\subsection{Variable and measurement}

For measuring the construct TQM, this paper basically adopts the instrument used by Chenhall (1997). It includes 7 items largely based on TQM dimensions. Accordingly, the instrument will help to enquire TQM dimensions. The top management asked to rate the degree of each question based on its implementation in their organization's by using a five-point Likert scale. For the BSC on the other hand, the variable was measured using an instrument that was developed by Kaplan \& Norton (1996). The instrument contains 21 items for the four perspectives of BSC: 4 are financial items and 17 non-financial items from three different perspectives of customer, internal business process, and learning and growth perspective. The respondents were asked to indicate the extent to which each item is used in assessing performance, using a five-point Likert scale.

\section{Results}

Partial Least Square Structural Equation Model (PLS SEM) was used in this paper utilising Smart PLS 3.0 software (Ringle, Wender \& Becker, 2015) in analysing both measurement and structural models. The measurement model was determined by running PLS algorism while the structural model was determined through bootstrapping method (Hair et al., 2014).

\subsection{Respondent}

Descriptive analysis shows that majority of the respondents were males with total percent $76.4 \%$ of the sample while $23.6 \%$ of respondents were females. The results indicate that the industrial sector in Iraq employs more males than females due to the nature of society. In terms of age, sample subjects' age ranged from 20 to above 60 years. $36.2 \%$ of the sample age between 41 and 50 years, $28.2 \%$ of the sample age between 31 and 40 years, $\% 20.6$ of the sample age between 51 and $60,13.3 \%$ of the sample age is between 21 and 30 years and only $1.7 \%$ of the sample age is above 60 . In terms of position, the majority of respondents $(59.1 \%$ ) are account managers, $28.2 \%$ of respondents are managers, $7.6 \%$ are audit managers, and $3.7 \%$ are assistant managers. This is an indication that members of the top management are utilised for the survey. In terms of industry, the majority (78\%) of respondent firms are 


\section{Macrothink}

from four industries: \% 21.6 are Textile and wearing apparel firms; \% 19.9 are Food and beverage firms; \% 13 are Non-metallic mineral firms; \% 12 are Chemical products firms ; \% 11.3 are wood and wood products firms. The other $22 \%$ of firms are from Paper and paper products with $6 \%$, Electrical and electronic with 5.6\%, Iron and steel with \% 4.3, Plastic products with \% 4 and Machinery products with \%. This is an indication that the survey covers divers companies with different line of activities.

\subsection{Measurement Model}

Convergent and discriminant validity was used in evaluating the measurement model of the paper. All the construct of this paper has achieved the required loading above 0.7 , composite reliability above 0.7 and AVE above 0.5 (Hair et al., 2014). However, two items CP1 and CP6 from the construct customer perspective are deleted from further analysis due to the low loading (see figure 2 and Table 1).

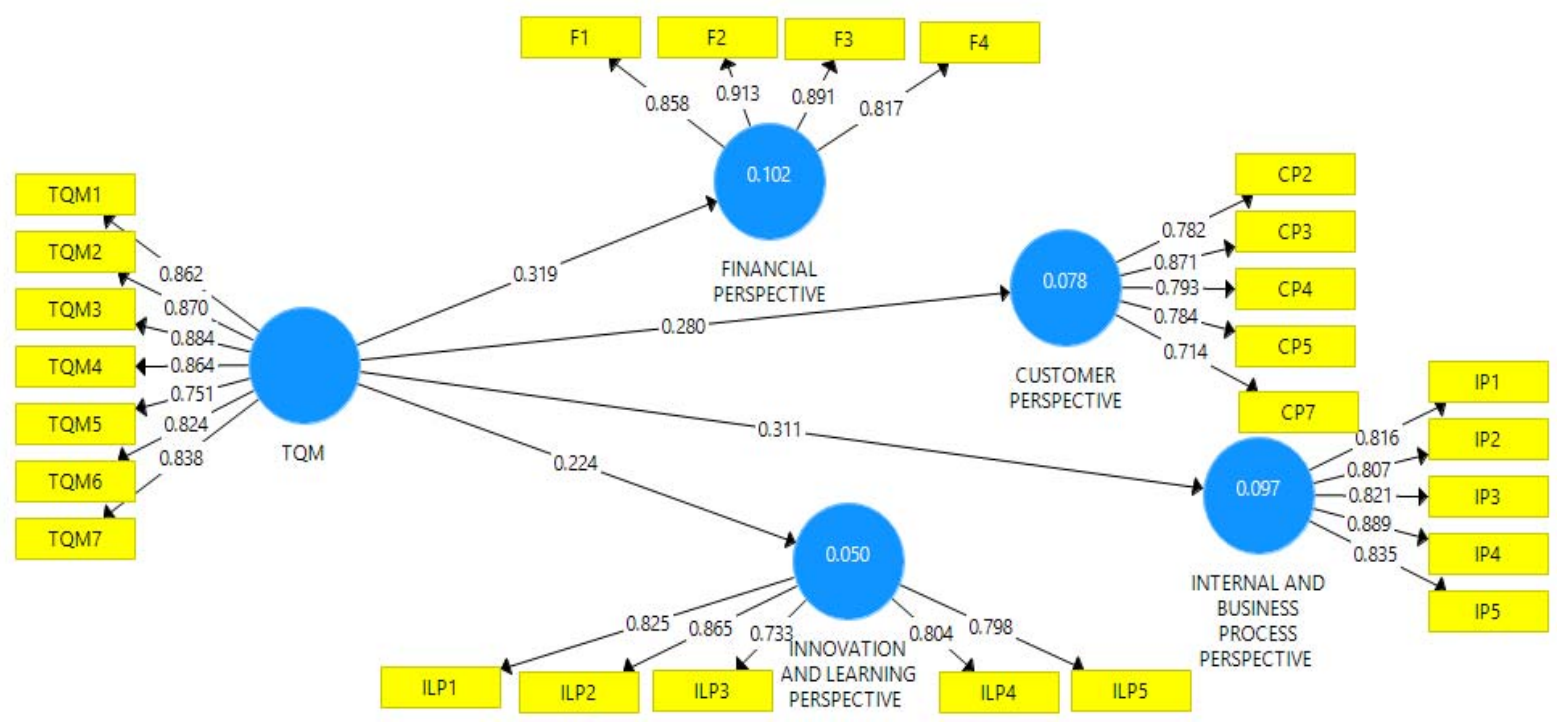

Figure 2. Measurement model

The discriminant validity analysis result is shown in Table 2 . The square roots of AVE for all the constructs are on the diagonal line signifying a higher square root of AVE. All the square roots of AVE for the constructs are greater than the off-diagonal correlation coefficients in the corresponding rows and columns. In addition, this indicates that each and every variable shares more variance with its items than with other constructs, and, thus supports discriminant validity (Hair et al., 2010). 


\section{Macrothink}

Table 1. Reliability and Validity of Construct

\begin{tabular}{|c|c|c|c|c|c|}
\hline Variable & $\begin{array}{c}\text { Indicator } \\
\mathrm{s}\end{array}$ & Loading & $\begin{array}{c}\text { Cronbach's } \\
\text { alpha }\end{array}$ & $\begin{array}{l}\text { Composite } \\
\text { Reliability }\end{array}$ & AVE \\
\hline BSC: Customer & $\mathrm{CP} 2$ & 0.782 & \multirow{5}{*}{0.853} & \multirow{5}{*}{0.892} & \multirow{5}{*}{0.625} \\
\hline \multirow[t]{4}{*}{ Perspective } & $\mathrm{CP} 3$ & 0.871 & & & \\
\hline & $\mathrm{CP} 4$ & 0.793 & & & \\
\hline & $\mathrm{CP5}$ & 0.784 & & & \\
\hline & $\mathrm{CP} 7$ & 0.714 & & & \\
\hline BSC: Financial & $\mathrm{F} 1$ & 0.858 & \multirow{4}{*}{0.895} & \multirow{4}{*}{0.926} & \multirow{4}{*}{0.758} \\
\hline \multirow[t]{3}{*}{ Perspective } & $\mathrm{F} 2$ & 0.913 & & & \\
\hline & F3 & 0.891 & & & \\
\hline & $\mathrm{F} 4$ & 0.817 & & & \\
\hline BSC: Innovation and & ILP1 & 0.825 & \multirow{5}{*}{0.872} & \multirow{5}{*}{0.902} & \multirow{5}{*}{0.650} \\
\hline \multirow[t]{4}{*}{ Learning perspective } & ILP2 & 0.865 & & & \\
\hline & ILP3 & 0.733 & & & \\
\hline & ILP4 & 0.804 & & & \\
\hline & ILP5 & 0.798 & & & \\
\hline BSC: Internal Business & IP1 & 0.816 & \multirow{5}{*}{0.891} & \multirow{5}{*}{0.919} & \multirow{5}{*}{0.696} \\
\hline \multirow[t]{4}{*}{ Process Perspective } & IP2 & 0.807 & & & \\
\hline & IP3 & 0.821 & & & \\
\hline & IP4 & 0.889 & & & \\
\hline & IP5 & 0.835 & & & \\
\hline Total Quality & TQM1 & 0.862 & \multirow{7}{*}{0.932} & \multirow{7}{*}{0.945} & \multirow{7}{*}{0.710} \\
\hline \multirow[t]{6}{*}{ Management } & TQM2 & 0.870 & & & \\
\hline & TQM3 & 0.884 & & & \\
\hline & TQM4 & 0.864 & & & \\
\hline & TQM5 & 0.751 & & & \\
\hline & TQM6 & 0.824 & & & \\
\hline & TQM7 & 0.838 & & & \\
\hline
\end{tabular}

Table 2. Discriminant Validity

\begin{tabular}{lccccc}
\hline Variable & BSC CP & BSC FP & BSC ILP & BSC IP & TQM \\
\hline BSC: Customer Perspective & $\mathbf{0 . 7 9 0}$ & & & & \\
$\begin{array}{l}\text { BSC: Financial Perspective } \\
\text { BSC: Innovation and Learning }\end{array}$ & 0.436 & $\mathbf{0 . 8 7 1}$ & & & \\
perspective & 0.350 & 0.447 & $\mathbf{0 . 8 0 6}$ & & \\
$\begin{array}{l}\text { BSC: Internal Business Process } \\
\text { Perspective }\end{array}$ & 0.432 & 0.449 & 0.328 & $\mathbf{0 . 8 3 4}$ & \\
Total Quality Management & 0.280 & 0.319 & 0.224 & 0.311 & $\mathbf{0 . 8 4 3}$ \\
\hline
\end{tabular}

\subsection{Structural Model}

The structural model was assessed by evaluating the beta value and the corresponding t-values through the bootstrapping procedure with 500 resample. Therefore, the bootstrapping 
result from the Smart PLS reveals that path coefficient from TQM -> CP is statistically significant with a beta $(\beta)$ value of 0.280 , t-value of 5.245 and a $p$-value of 0.000 significant at the $p<0.01$. the result also shows significance on the effect of TQM on FP the result shows beta $(\beta)$ value of 0.319 , t-value of 6.296 and a $p$-value of 0.000 , significance at $p<0.01$. for the effect of TQM on IL the result shows beta $(\beta)$ value of 0.224 , t-value of 4.678 and a $\mathrm{p}$-value of 0.000 , significance at $\mathrm{p}<0.01$ and finally the result also shows significant effect of TQM on IP with beta value of 0.311 and t-value 5.534. (see Figure 3 and Table 3).

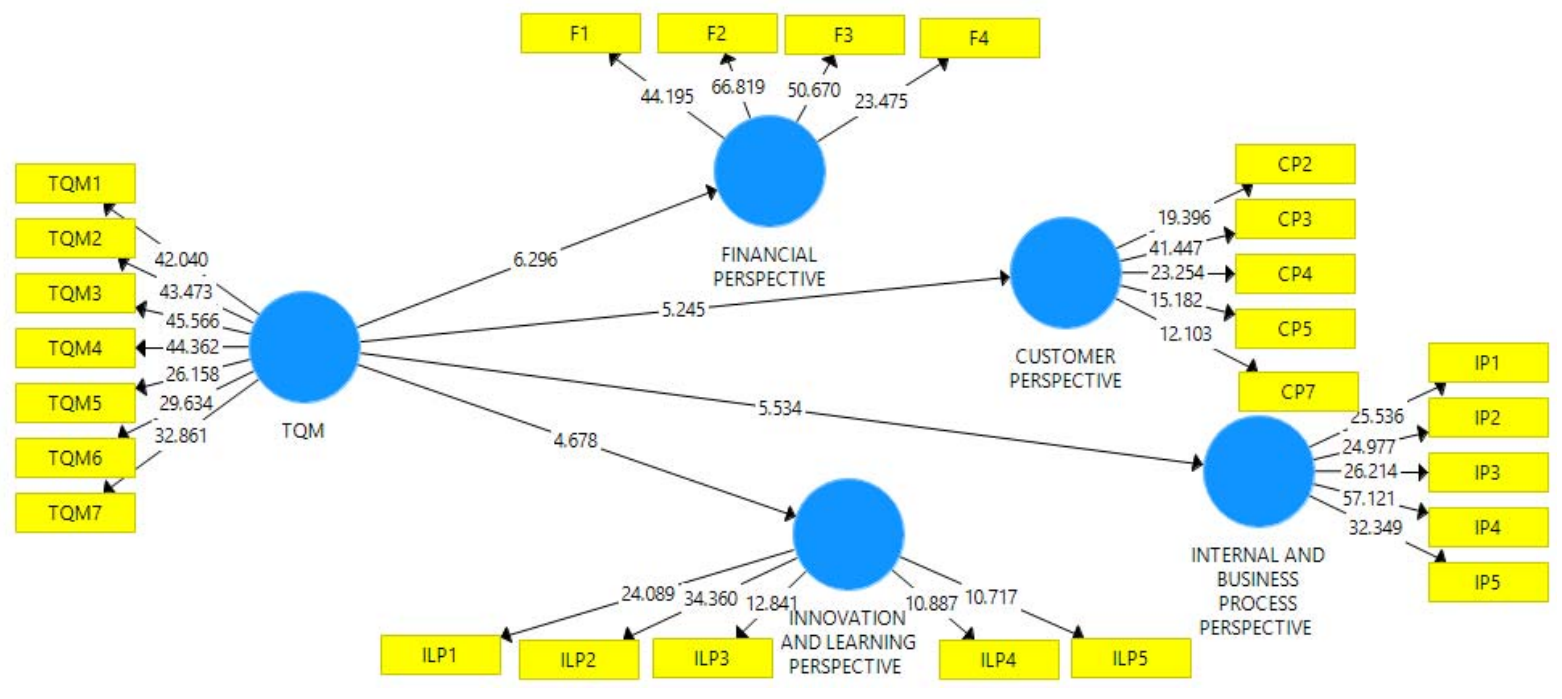

Figure 3. Structural model

Table 3. Result of the structural model analysis

\begin{tabular}{lcccc}
\hline Relationship & Beta & Standard Dev. & T Statistics & P Values \\
\hline TQM -> CP & 0.280 & 0.053 & 5.245 & 0.000 \\
TQM -> FP & 0.319 & 0.051 & 6.296 & 0.000 \\
TQM -> IL & 0.224 & 0.048 & 4.678 & 0.000 \\
TQM -> IP & 0.311 & 0.056 & 5.534 & 0.000 \\
\hline
\end{tabular}

\subsection{Discussion of Findings}

This paper empirically assessed a structural model of the integration between TQM and BSC in the manufacturing industry of Iraq. The perceptions of management of the manufacturing companies were used in the analysis and the findings show a positive significant relationship between TQM and all the perspective of BSC (customer, financial, innovation and learning, and internal business process).

The implication of this finding is that the management of Iraqi manufacturing companies are with vies that TQM can best be a matched to BSC for better performance. By extension, the finding of this paper implies that for the companies to compete favorable in the industry it need to integrate the technique of TQM with dimensions of BSC. This finding is consistent with previous studies (Mehralian et al., 2017; Sholihin \& Laksmi, 2009). 


\section{Conclusion}

This paper was set to examine the integration between TQM and BSC based on its four perspectives. The result shows a significant link between TQM and the perspective of BSC (customer, financial, innovation and learning, and internal business process). Therefore, this paper concludes that TQM is a good technique of strategic cost and management account that have a direct positive link with the organizational performance from the customer perspective, financial perspective, innovation and learning perspective, and internal business process perspective of BSC. This implies that Iraqi manufacturing industries can attain the performance of their companies in the different perspective of BSC by proper implementation of TQM technique.

\section{Acknowledgements}

The author would like to thank Ministry of Higher Education \& Scientific Research of Iraq and my supervisor Dr. Rapiah Mohamed for her guidelines and efforts. A special thanks also to the anonymous reviewers and the journal editor.

\section{References}

Acar, A. Z., \& Acar, P. (2014). Organizational culture types and their effects on organizational performance in Turkish hospitals. Emerging Markets Journal, 3(3), 18-31. https://doi.org/10.5195/EMAJ.2014.47

Al-Naser, K. (2010). The Completeness between the financial and non-financial measures for achieve monitoring on the operating process. Tanmiat Al-Rafidain Journal, 32(99). 1-33.

Atkinson, A., Balakrishnan, R., Booth, P., Jeans, M., Cote, T., Grout, T., Mali, H., Roberts, E., Ulan, \& Wu. A. (1997). New Directions in Management Accounting Research. Journal of Management Accounting Research; Sarasota, 9, 79-108.

Ayedh, A., \& Eddine, H. (2015). The impact of advance management accounting techniques on performance: The case of Malaysia. Middle East Journal of Business, 10(2).

Bureihi, F. (2011). Iraqi economy ... opportunities and challenges. Baghdad College of Economic Sciences University Journal, 27, 21-56.

Central Bank of Iraq, Annual Report. (2013). Statistics \& Research Department. Retrieved from http://www.cbi.iq

Chenhall, R. (1997).Reliance on manufacturing performance measures, total quality management and organizational performance. Management Accounting Research, 8(2), 187-206. https://doi.org/10.1006/mare.1996.0038

Chenhall, R. H., \& Langfield-Smith, K. (2007). Multiple perspectives of performance measures. European Management Journal, 25(4), 266-282. https://doi.org/10.1016/j.emj.2007.06.001

Elijido-Ten, E. (2010). Public disclosure of strategic performance measurement system: An Australian investigation. International Handbook of Academic Research and Teaching, 38. 
Eriksson, H., \& Hansson, J. (2003). The impact of TQM on financial performance. Measuring Business Excellence, 7(1), 36-50.

Gupta, K. M., \& Gunasekaran, A. (2005). Costing in new enterprise environment: A challenge for managerial accounting researchers and practitioners. Managerial Auditing Journal, 20(4), 337-353. https://doi.org/10.1108/02686900510592034

Hafedh, M., Akoum, I., Zbib, I. J., \& Ahmed, Z. U. (2007). Iraq: emergence of a new nation from the ashes. International Journal of Emerging Markets, 2(1), 7-21. https://doi.org/10.1108/17468800710718868

Hair Jr, J., Sarstedt, M., Hopkins, L., \& G. Kuppelwieser, V. (2014). Partial least squares structural equation modeling (PLS-SEM) An emerging tool in business research. European Business Review, 26(2), 106-121. https://doi.org/10.1108/EBR-10-2013-0128

Hair, J. F., Wolfinbarger, M. F., Ortinau, D. J., \& Bush, R. P. (2008). Essentials of marketing research. McGraw-Hill/Higher Education.

Harash, E., Al-Tamimi, K., \& Al-Timimi, S. (2014). The relationship between government policy and financial performance: A study on the SMEs in Iraq. China-USA Business Review, 13(4).

Hertati, L., \& Sumantri, R. (2016). Just In Time, Value Chain, Total Quality Management, Part Of Technical Strategic Management Accounting. International Journal of Technology Enhancements and Emerging Engineering Research, 5(4), 180-191.

Hertati, L. (2015). Total Quality Management as Technics on Strategic Management Accounting. International Journal of Recent Advances in Multidisciplinary Research, 2(11), 942-949

Hoque, Z. (2003). Total quality management and the balanced scorecard approach: A critical analysis of their potential relationships and directions for research. Critical Perspectives on Accounting, 14(5), 553-566. https://doi.org/10.1016/S1045-2354(02)00160-0

Hoque, Z. (2014). 20 years of studies on the balanced scorecard: Trends, accomplishments, gaps and opportunities for future research. The British Accounting Review, 46(1), 33-59. https://doi.org/10.1016/j.bar.2013.10.003

Hoque, Z., \& James, W. (2000). Linking balanced scorecard measures to size and market factors: Impact on organizational performance. Journal of Management Accounting Research, 12, 1-17. https://doi.org/10.2308/jmar.2000.12.1.1

Hoque, Z., Mia, L., \& Alam, M. (2001). Market competition, computer-aided manufacturing and use of multiple performance measures: An empirical study. British Accounting Review, 33(1), 23-45. https://doi.org/10.1006/bare.2000.0149

Ibrahim, S., Sukeri, S. N., \& Rashid, I. M. (2014). Factors influencing the diffusion \& implementation of management accounting innovations (MAIS), Malaysian manufacturing industries in Nothern Region. Advances in Environmental Biology, 504-513. 
Johnson, H. T., \& Kaplan, R. S. (1987). The rise and fall of management accounting. IEEE Engineering Management Review, 3(15), 36-44. https://doi.org/10.1109/EMR.1987.4306297

Kaplan, R. S., \& Norton D. P. (1996). The balanced scorecard: Translating strategy into action. Boston: Harvard Business School Press.

Kaplan, R. S., \& Norton, D. P. (1992). The balanced scorecard-measures that drive performance. Harvard Business Review, 70(1), 71-79.

Kaplan, R. S., \& Norton, D. P. (1993). Putting the balanced scorecard to work. Harvard Business Review, 71(5), 134-147.

Kaplan, R. S., \& Norton, D. P. (2001). Transforming the balanced scorecard from performance measurement to strategic management: Part 1. Accounting Horizons, 15(1), 87-104. https://doi.org/10.2308/acch.2001.15.1.87

Kartalis, N., Velentzas, J., \& Broni, G. (2013). Balance scorecard and performance measurement in a greek industry. Procedia Economics and finance, 5, 413-422. https://doi.org/10.1016/S2212-5671(13)00049-X

Krejcie, R. V., \& Morgan, D. W. (1970). Determining sample size for research activities. Educational and psychological measurement, 30(3), 607-610. https://doi.org/10.1177/001316447003000308

Lin, Z. J., \& Johnson, S. (2004). An exploratory study on accounting for quality management in China. Journal of Business Research, 57(6), 620-632. https://doi.org/10.1016/S0148-2963(02)00424-1

Lynch, R. L., \& Cross, K. F. (1992). Measure up!: The essential guide to measuring business performance. Mandarin.

Malleret, V. (2015). Revisiting 30 years of SMA literature: A focus on cost, price and value, Communication to the 38th EAA Annual Congress Glasgow 28-30 April 2015

Mathews, J., \& Katel, P. (1992). The cost of quality. Newsweek, 120(10), 48-49.

Mehralian, G., Mehralian, G., Nazari, J. A., Nazari, J. A., Nooriparto, G., Nooriparto, G., \& Rasekh, H. R. (2017). TQM and organizational performance using the balanced scorecard approach. International Journal of Productivity and Performance Management, 66(1), 111-125.

Mohamed, R., Wee, S. H., Abdul Rahman, I. K., \& Abdul Aziz, R. (2010). Strategic performance measurement system, organizational capabilities and competitive advantage. Asian Journal of Accounting and Governance, 1, 27-50. https://doi.org/10.17576/ajag-2010-1-6545

Neely, A. D., Mills, J., Platts, K., Gregory, M., \& Richards, H. (1994). Realizing strategy through measurement. International Journal of Operations \& Production Management, 14(3), 140-152. https://doi.org/10.1108/01443579410058603 
Norreklit, H., Norreklit, L., Mitchell, F., \& Bjornenak, T. (2012). The rise of the balanced scorecard! Relevance regained?. Journal of Accounting \& Organizational Change, 8(4), 490-510. https://doi.org/10.1108/18325911211273491

Peljhan, D., \& Marc, M. (2016). Total quality management and performance management systems: team players or lonely riders?. Total Quality Management \& Business Excellence, 1-21. https://doi.org/10.1080/14783363.2016.1253464

Pimentel, L., \& Major, M. J. (2014). Quality management and a balanced scorecard as supporting frameworks for a new management model and organisational change. Total Quality $\begin{array}{llll}\text { Management } \& \quad \text { Business } \quad \text { Excellence, } & \text { 25(7-8), }\end{array}$ https://doi.org/10.1080/14783363.2014.904568

Prajogo, D. I., \& Brown, A. (2004). The relationship between TQM practices and quality performance and the role of formal TQM programs: An Australian empirical study. The Quality Management Journal, 11(4), 31.

Ringle, C. M., Wende, S., \& Becker, J. M. (2015). SmartPLS 3. Boenningstedt: SmartPLS $\mathrm{GmbH}, \mathrm{http}: / /$ www. smartpls. com.

Sandström, J., \& Toivanen, J. (2002). The problem of managing product development engineers: Can the balanced scorecard be an answer?. International Journal of Production Economics, 78(1), 79-90. https://doi.org/10.1016/S0925-5273(01)00199-2

Shafiq, M., Lasrado, F., \& Hafeez, K. (2017). The effect of TQM on organisational performance: empirical evidence from the textile sector of a developing country using SEM. Total Quality Management \& Business Excellence, 1-22. https://doi.org/10.1080/14783363.2017.1283211

Shank, J. K. (1989). Strategic cost management: new wine, or just new bottles. Journal of Management Accounting Research, 1(1), 47-65.

Sholihin, M., \& Laksmi, A. C. (2009). Total quality management, balanced scorecard and performance. Journal Akuntansi dan Auditing Indonesia, 13(1), 13-28.

Srour, M. (2014). Using financial and non-financial measurements of cost of quality to strategic planning evaluation. Paper presented at The Third Scientific Conference of Federal Board of Supreme Audit - Republic of Iraq. Retrieved from http://www.d-raqaba-m.iq/pdf/manal_3.pdf

Sunhilde, C. U. C. (2009). Balanced Scorecard And The Management Intruments Complementarity. The Annals of the" Stefan cel Mare" University of Suceava. Fascicle of The Faculty of Economics and Public Administration 9, 2(10), 119-124.

Sweis, R. J., Ahmad, K. M. A., Al-Dweik, G. A., Alawneh, A. R., \& Hammad, A. A. (2016). The relationship between total quality management practices and organisational performance at Jordanian hospitals. International Journal of Business Innovation and Research, 10(4), 519-542. 


\section{Macrothink}

Asian Journal of Finance \& Accounting ISSN 1946-052X

Vora, M. K. (2004). Creating employee value in a global economy through participation, motivation and development. Total Quality Management \& Business Excellence, 15(5-6), 793-806. https://doi.org/10.1080/14783360410001680242

Walton, M. (1986). The deming management method. London: Mercury.

Widener, S. (2006). Associations between strategic resource importance and performance measure use: The impact on firm performance. Management Accounting Research, 17(4), 433-457. https://doi.org/10.1016/j.mar.2005.10.002

Wilkinson, A., Marchington, M., Goodman, J., \& Ackers, P. (1992). Total quality management and employee involvement. Human Resource Management Journal, 2(4), 1-20. https://doi.org/10.1111/j.1748-8583.1992.tb00263.x 